\title{
The effect of grazing by cattle on animal performance and floristic composition in Nardus-dominant swards
}

\author{
T. G. Common, I. A. Wright and S. A. Grant \\ Macaulay Land Use Research Institute, Craigiebuckler, Aberdeen AB9 2QJ
}

\section{Introduction}

Nardus stricta (White bent) is currently estimated to dominate over $20 \%$ of native grasslands in the United Kingdom and this area is generally accepted to be increasing. The increase in Nardus may be due to a decrease in the ratio of cattle to sheep grazing native grasslands since sheep are more able to select the preferred between-tussock grasses (Grant, Suckling, Smith, Torvell, Forbes and Hodgson, 1985). Research using non-lactating cows has indicated that semi-natural plant communities dominated by Nardus stricta tussocks can be manipulated by grazing with cattle (Grant, Torvell, Armstrong and Beattie, 1987; Hodgson, Forbes, Armstrong, Beattie and Hunter, 1991). A management regime was identified in which dry cows gained weight and the proportion of Nardus in the sward declined with time. There is no equivalent information on the relationship between the levels of Nardus utilization and the levels of performance that can be sustained by lactating beef cows and their calves. A long-term large-scale experiment was set up in 1988 to provide this information.

\section{Material and methods}

\section{Treatments}

An area of 25 ha of Nardus-dominant grassland was divided into four plots to provide two replicated treatments. Each plot was grazed by six experimental Blue-Grey lactating beef cows and their spring-born Charolais-cross calves. Additional cows and calves were added or removed to maintain the preferred between-tussock grasses at heights of either 4 to 5 or 6 to $7 \mathrm{~cm}$. Grazing began when target sward heights were reached in spring (usually mid to late May) and continued until only two cows remained on each plot (usually early September).

\section{Measurements}

Records were kept of stocking density. Cows and calves were weighed every 2 weeks and whenever they were moved on or off plots. Milk yields were measured using an oxytocin and machine milking technique during each intake measurement period.
The floristic composition and structure of the sward were recorded in May each year using an inclined point quadrat at pre-determined positions in each plot. The proportion of Nardus leaves showing signs of grazing and the grazed leaf lengths were measured in July and at the end of grazing.

\section{Results and discussion}

Preliminary results are available for the first 4 years of the experiment. In the 1st year the proportion of Nardus tillers grazed (Table 1) on the 4 to $5 \mathrm{~cm}$ treatment was twice that on the 6 to $7 \mathrm{~cm}$ treatment (71 v. 36\%). During the following 3 years the proportion of grazed Nardus tillers on the 6 to $7 \mathrm{~cm}$ treatment increased to over $65 \%$. The Nardus leaves were also more closely grazed on the 4 to $5 \mathrm{~cm}$ than on the 6 to $7 \mathrm{~cm}$ treatment $(64 v .105 \mathrm{~cm})$.

However, the 4 to $5 \mathrm{~cm}$ treatment resulted in a significant reduction in individual cow live-weight change $(-0.04$ v. $0.36 \mathrm{~kg} /$ day $)$.

Calves also gained less live weight on the 4 to $5 \mathrm{~cm}$ treatment, although the difference was less during

Table 1 Nardus utilization

\begin{tabular}{lrrrr}
\hline \hline & 1988 & 1989 & 1990 & 1991 \\
\hline $\begin{array}{l}\text { Percentage of Nardus } \\
\text { tillers grazed }\end{array}$ & & & & \\
4 to $5 \mathrm{~cm}$ treatment & 71.2 & 82.0 & 86.8 & 86.2 \\
$\quad 6$ to $7 \mathrm{~cm}$ treatment & 36.0 & 40.2 & 67.6 & 61.2 \\
$\begin{array}{l}\text { Grazed leaf length (mm) } \\
4 \text { to } 5 \mathrm{~cm} \text { treatment }\end{array}$ & 80.9 & 59.6 & 59.3 & 55.5 \\
6 to $7 \mathrm{~cm}$ treatment & 113.2 & 110.8 & 98.6 & 97.0 \\
\hline
\end{tabular}

Table 2 Cow live-weight gain ( $\mathrm{kg} /$ day $)$

\begin{tabular}{lrrrr}
\hline \hline & 1988 & 1989 & 1990 & 1991 \\
\hline 4 to $5 \mathrm{~cm}$ treatment & -0.03 & 0.07 & -0.19 & 0.00 \\
6 to $7 \mathrm{~cm}$ treatment & 0.31 & 0.47 & 0.32 & 0.35 \\
\hline
\end{tabular}


the first 5 to 6 weeks of grazing $(0.77 v .0 .88 \mathrm{~kg} /$ day $)$ than later in the season $(0.46 v .0 .81 \mathrm{~kg} /$ day $)$. This was mainly a consequence of reduced milk production of cows on the 4 to $5 \mathrm{~cm}$ treatment, since milk yields were proportionately about 0.13 higher on the 6 to $7 \mathrm{~cm}$ treatment during early June but 0.32 higher by the end of July although milk yields declined with time on both treatments.

\section{Conclusions}

It is concluded that high levels of Nardus utilization are incompatible with high levels of individual animal performance in lactating cows although short periods of high utilization may give acceptable performance. Lower levels of utilization such as achieved on the 6 to $7 \mathrm{~cm}$ treatment results in moderate levels of animal performance and appear to control Nardus over a longer period of time.

\section{References}

Grant, S. A., Suckling, D. E., Smith, H. K., Torvell, L., Forbes, T. D. A. and Hodgson, J. 1985. Comparative studies of diet selection by sheep and cattle: the hill grasslands. Journal of Ecology 73: 987-1004.

Grant, S. A., Torvell, L., Armstrong, R. H. and Beattie, M. M. 1987. The manipulation of mat-grass pasture by grazing management. In Agriculture and conservation in the hills and uplands (ed. M. Bell and R. G. M. Bunce). Institute of Terrestrial Ecology, Marled.

Hodgson, J., Forbes, T. D. A., Armstrong, R. H., Beattie, M. M. and Hunter, E. A. 1991. Comparative studies of the ingestive behaviour and herbage intake of sheep and cattle grazing indigenous hill plant communities. Journal of Applied Ecology 28: 205-227. 